\title{
ANALISIS LAPORAN KEUANGAN SEBAGAI DASAR DALAM PENILAIAN KINERJA KEUANGAN PT. BUDI SATRIA WAHANA MOTOR
}

\author{
Riswan \\ Yolanda Fatrecia Kesuma \\ (Universitas Bandar Lampung)
}

\begin{abstract}
This research aims to analyze the financial performance of PT BUDI SATRIA MOTOR VEHICLE in terms of the ratio of solvency, liquidity, profitability and activity ratios in 2009 until 2012.

This study uses data collected in 2009-2012 for financial data company. The Data used in this study is secondary data, where writers get data indirectly through intermediaries and media studies libraryPenelitian ini Based on the results of the research, it can be concluded that the company's financial performance has not been good. In terms of liquidity ratio, whereby cash and banks haven't been able to guarantee the debt. Review of the solvency ratio, the large amount of debt is not comparable to that of its own capital. On the ratio of profitability, where this ratio tends to decrease. And on the ratio of the activity, the company has showed an increase. From the research, that suggested company to pt.Budi satria the motor had to do the analysis ratio to know further about condition or circumstances of corporate finance.
\end{abstract}

Keywords:Financial Report, Ratio Liquidity, Ratio Solvability, Ratio Profitablitas, Ratio Activity

\section{Latar Belakang Masalah}

Kinerja keuangan merupakan gambaran setiap hasil ekonomi yang mampu di raih oleh perusahaan pada periode tertentu melalui aktivitas-aktivitas perusahaan untuk menghasilkan keuntungan secara efektif dan efisien. Kinerja keuangan perusahaan dapat di ukur dengan menganalisa dan mengevaluasi laporan keuangan. Informasi posisi keuangan dan kinerja keuangan digunakan sebagai dasar untuk memprediksi posisi keuangan dan kinerja di masa depan. Informasi yang tersaji di dalam laporan keuangan memberikan gambaran mengenai kondisi dan kinerja keuangan perusahaan dalam satu periode. Menurut pernyataan PSAK 1 (revisi 2009) yang dikeluarkan oleh IAI menyatakan bahwa suatu perusahaan diwajibkan untuk membuat laporan keuangan yang terdiri dari neraca, laporan laba rugi, laporan ekuitas, laporan arus kas, dan catatan atas laporan keuangan.

Laporan keuangan suatu perusahaan sangatlah diperlukan, dikarenakan laporan keuangan diharapkan dapat memberikan informasi tentang arus masuk maupun arus keluar 
keuangan perusahaan. Laporan keuangan merupakan perangkat khusus yang digunakan dalam mengevaluasi kinerja perusahaan, kinerja aktivitas operasi, aktivitas investasi, dan aktivitas pendanaan. Salah satu sumber informasi yang dapat digunakan adalah dengan menganalisis rasio laporan keuangan adalah dengan menganalisa rasio likuiditas, rasio solvabilitas, rasio profitabilitas, dan rasio aktivitas. Adapun tujuan penelitian kinerja keuangan perusahaan menurut Munawir (2000:31) adalah sebagai berikut:

a. Untuk mengetahui tingkat likuiditas, yaitu kemampuan perusahaan untuk memperoleh kewajiban keuangan yang harus segera dipenuhi perusahaan untuk memenuhi keuangannya pada saat ditagih.

b. Untuk mengetahui tingkat solvabilitas, yaitu kemampuan perusahaan untuk memenuhi kewajiban keuangannya apabila perusahaan tersebut dilikuidasi baik kewajiban keuangan jangka pendek maupun jangka panjang.

c. Untuk mengetahui tingkat rentabilitas atau profitabilitas, yaitu menunjukan kemampuan perusahaan untuk menghasilkan laba selama periode tertentu.

d. Untuk mengetahui tingkat stabilitas usaha, yaitu kemampuan perusahaan untuk melakukan usahanya dengan stabil, yang diukur dengan mempertimbangkan kemampuan perusahaan untuk membayar beban bunga atas hutang-hutangnya termasuk membayar kembali pokok hutangnya tepat pada waktunya serta kemampuan membayar deviden secara teratur kepada para pemegang saham tanpa mengalami hambatan atau krisis keuangan.

\section{Landasan Teori}

\subsection{Pengertian Laporan Keuangan}

Laporan keuangan adalah catatan informasi keuangan suatu perusahaan pada suatu periode akuntansi yang dapat digunakan untuk menggambarkan kinerja perusahaan. Laporan keuangan adalah bagian dari proses pelaporan keuangan. Kondisi keuangan suatu perusahaan akan dapat diketahui dari laporan keuangan perusahaan yang bersangkutan, yang terdiri dari neraca, laporan laba rugi serta laporan keuangan lainnya. Memuat Baridwan (2004:17) mendefinisikan laporan keuangan merupakan ringkasan dari suatu proses pencatatan, merupakan suatu ringkasan dari taransaksi-transaksi keuangan yang terjadi selama tahun buku yang bersangkutan.

Berdasarkan beberapa pendapat tersebut di atas dapat disimpulkan bahwa laporan keuangan merupakan daftar untuk mengetahui jumlah kekayaan perusahaan pada periode 
tertentu, dalam bentuk neraca dan laporan laba rugi. Dipandang dari sudut pandang yang berkepentingan, ada tiga jenis laporan keuangan, yaitu laporan keuangan untuk manajmen, laporan keuangan untuk pihak eksternal perusahaan, dan laporan keuangan untuk pihak-pihak khusus. Laporan keuangan untuk ketiga pihak tersebut disusun dan disajikan dari suatu proses akuntansi yang sama, yaitu merupakan produk dari sebuah system informasi akuntansi.

Menurut Sutrisno (2008: 9), "Laporan Keuangan merupakan hasil dari proses akuntansi yang meliputi dua laporan utama yakni 1.Neraca dan (2) Laporan Laba Rugi. Setiap perusahaan mempunyai laporan keuangan yang bertujuan menyediakan informasi yang menyangkut posisi keuangan, kinerja serta perubahan posisi keuangan suatu perusahaan yang bermanfaat bagi sejumlah besar pemakai laporan keuangan dalam pengambilan keputusan secara ekonomi. Menurut Weygandt, et al. (2008: 58), FASB menyimpulkan bahwa tujuantujuan dari pelaporan keuangan adalah untuk menyediakan informasi yang:

1. Berguna bagi mereka yang membuat keputusan investasi dan kredit.

2. Membantu dalam memperkirakan arus kas di masa depan.

3. Mengidentifikasi sumber daya ekonomi (asset), klaim atas sumber daya tersebut (kewajiban) serta perubahan pada sumber daya dank laim tersebut.

Menurut Ikatan Akuntan Indonesia (2009:3), tujuan laporan keuangan adalah menyediakan informasi yang menyangkut posisi keuangan, kinerja, serta perubahan posisi keuangan suatu perusahaan yang bermanfaat bagi sejumlah besar pemakai dalam pengambilan keputusan ekonomi. Sedangkan menurut Fahmi (2011:28), tujuan utama dari laporan keuangan adalah memberikan informasi keuangan yang mencakup perubahan dari unsur-unsur laporan keuangan yang ditujukan kepada pihak-pihak lain yang berkepentingan dalam menilai kinerja keuangan terhadap perusahaaan di samping pihak manajemen perusahaan.

Para pemakai laporan akan menggunakan untuk meramalkan, membandingkan, dan menilai dampak keuangan yang timbul dari keputusan ekonomis yang diambil. Informasi mengenai dampak keuangan yang timbul tadi sangat berguna bagi pemakai untuk meramalkan, membandingkan dan menilai keuangan. Seandainya nilai uang tidak stabil, maka hal ini akan dijelaskan dalam laporan keuangan. Laporan keuangan akan lebih bermanfaat apabila dilaporkan tidak saja aspek-aspek kuantitatif, tetapi mencakup penjelasanpenjelasan lainnya yang dirasakan perlu. Dan informasi ini harus faktual dan dapat diukur secara objektif. 


\subsection{Komponen Laporan Keuangan}

Menganalisis suatu laporan keuangan, penganalisa harus mempunyai pengertian yang mendalam tentang laporan keuangan itu sendiri dan bentuk-bentuk maupun prinsip-prinsip yang terkandung dalam laporan keuangan adalah sebagai berikut:

\section{Neraca}

Menurut Harahap (2009:107), neraca atau daftar neraca disebut juga laporan posisi keuangan perusahaan. Laporan ini menggambarkan posisi aset, kewajiban dan ekuitas pada saat tertentu. Neraca atau balance sheet adalah laporan yang menyajikan sumber-sumber ekonomis dari suatu perusahaan atau aset kewajiban-kewajiban atau utang, dan hak para pemilik perusahaan yang tertanam dalam perusahaan tersebut atau ekuitas pemilik suatu saat tertentu. Neraca harus disusun secara sistematis sehingga dapat memberikan gambaran mengenai posisi keuangan perusahaan. Oleh karena itu neracatepatnya dinamakan statements of financial position. Karena neraca merupakan potret atau gambaran keadaan pada suatu saat tertentu maka neraca merupakan status report bukan merupakan flow report.

Menurut Djarwanto (2004:20) mendefinisikan neraca adalah yang sistematis tentang aktiva (asset), utang (liabilities) dan modal sendiri (owner's equity) dari suatu perusahaan pada tanggal tertentu. Menurut Riyanto (2010:19), aset dapat dibagi atas dua kelompok besar, yaitu aset lancar adalah aset yang habis dalam satu kali perputaran dalam proses produksi dan proses berputarnya adalah dalam waktu yang pendek (umumnya kurang dari satu tahun).

Dalam perputarannya yang satu kali ini, elemen-elemen dari aset lancar tidak sama cepatnya ataupun tingkat perputarannya, misalnya piutang menjadi kas adalah lebih cepat daripada inventory (apabila penjualan dilakukan secara kredit), karena piutang menjadi kas hanya membutuhkan satu langkah saja, sedangkan inventory melalui piutang dahulu barulah menjadi kas. Dengan kata lain, aset lancar ialah aset yang dapat diuangkan dalam waktu pendek. Sedangkan aset tetap adalah aset yang tahan lama yang tidak atau secara berangsurangsur habis turut serta dalam proses produksi. Syarat lain untuk dapat diklasifikasikan sebagai aset tetap selain aset itu dimiliki perusahaan, juga harus digunakan dalam operasi yang bersifat permanen (aset tersebut mempunyai umum kegunaan jangka panjang atau tidak akan habis dipakai dalam satu periode kegiatan perusahaan).

Menurut Munawir (2010:18), hutang adalah semua kewajiban-kewajiban perusahaan kepada pihak lain yang belum terpenuhi, dimana hutang ini merupakan sumber dana atau 
modal perusahaan yang berasal dari kreditur. Hutang atau kewajiban-kewajiban perusahaan dapat dibebankan ke dalam kewajiban lancar (kewajiban jangka pendek) dan kewajiban jangka panjang. Kewajiban jangka pendek atau kewajiban lancar adalah kewajiban keuangan perusahaan yang pelunasannya atau pembayarannya akan dilakukan dalam jangka pendek (satu tahun sejak tanggal neraca) dengan menggunakan aset lancar yang dimiliki perusahaan, sedangkan kewajiban jangka panjang adalah kewajiban keuangan yang jangka waktu pembayaran (jatuh tempnya) jangka panjang (lebih dari satu tahun sejak tanggal neraca).

Menurut Riyanto (2010:240), modal sendiri merupakan ekuitas yang berasal dari pemilik perusahaan dan tertanam di dalam perusahaan untuk waktu yang tidak tertentu lamanya. Ekuitas dari sumber ini merupakan dana yang berasal dari pemilik perusahaan atau dapat pula bersumber dari pendapatan atau laba yang ditahan. Menurut Brigham dan Houston (2001:39) menjelaskan bahwa neraca adalah laporan posisi keuangan suatu perusahaan pada waktu tertentu. Melihat neraca pada saat tertentu akan dapat diketahui posisi keuangan suatu perusahaan pada saat tertentu.

\section{Laporan Laba Rugi}

Laporan laba rugi merupakan laporan prestasi perusahaan selama jangka waktu tertentu. Tujuan utama dari laporan laba rugi adalah melaporkan kemampuan perusahaan yang sebenarnya untuk memperoleh laba. Menurut Machfoedz dan Mahmudi (2008:1.21) laporan laba rugi (perhitungan sisa hasil usaha) adalah laporan tentang hasil usaha/operasi perusahaan atau badan lain selama jangka waktu periode akuntansi tertentu misalnya satu tahun.

Menurut Munawir (2010:26), laporan laba-rugi merupakan suatu laporan yang sistematis tentang penghasilan, beban, laba-rugi yang diperoleh oleh suatu perusahaan selama periode tertentu. Walaupun belum ada keseragaman tentang susunan laporan laba-rugi bagi tiap-tiap perusahaan, namun prinsip-prinsip yang umumnya diterapkan adalah sebagai berikut:

1. Bagian yang pertama menunjukan penghasilan yang diperoleh dari usaha pokok perusahaan (penjualan barang dagangan atau memberikan service) diikuti dengan harga pokok dari barang yang dijual, sehingga diperoleh laba kotor.

2. Bagian kedua menunjukan beban-beban operasional yang terdiri dari beban penjualan dan beban umum/administrasi (operating expenses). 
3. Bagian ketiga menunjukan hasil-hasil yang diperoleh di luar operasi pokok perusahaan, yang diikuti dengan beban-beban yang terjadi di luar usaha pokok perusahaan (non operating/financial income dan expenses).

4. Bagian keempat menunjukan laba atau rugi yang insidentil (extra ordinary gain or loss) sehingga akhirnya diperoleh laba bersih sebelum pajak pendapatan.

\section{Laporan Arus Kas}

Laporan arus kas atau laporan perubahan posisi keuangan menyajikan informasi aliran kas masuk atau keluar bersih pada suatu periode, hasil dari tiga kegiatan pokok perusahaan adalah operasi, investasi, dan pendanaan. Aliran kas diperlukan terutama untuk mengetahui kemampuan perusahaan yang sebenarnya dalam mengetahui kewajiban- kewajibannya.

\subsection{Analisi Laporan Keuangan}

\section{Pengertian Analisis Laporan Keuangan}

Menurut Munawir (2010:35), analisis laporan keuangan adalah analisis laporan keuangan yang terdiri dari penelaahan atau mempelajari daripada hubungan dan tendensi atau kecenderungan (trend) untuk menentukan posisi keuangan dan hasil operasi serta perkembangan perusahaan yang bersangkutan.

Berdasarkan penjelasan tersebut, dapat disimpulkan bahwa analisis laporan keuangan merupakan proses untuk mempelajari data-data keuangan agar dapat dipahami dengan mudah untuk mengetahui posisi keuangan, hasil operasi dan perkembangan suatu perusahaan dengan cara mempelajari hubungan data keuangan serta kecenderungan terdapat dalam suatu laporan keuuangan, sehingga analisis laporan keuangan dapat dijadikan sebagai dasar dalam pengambilan keputusan bagi pihak-pihak yang berkepentingan dan juga dalam melakukan analisisnya tidak akan lepas dari peranan rasio-rasio laporan keuangan, dengan melakukan analisis terhadap rasio-rasio keuangan akan dapat menentukan suatu keputusan yang akan diambil.

Sedangkan pengertian analisis laporan keuangan menurut Harahap (2006: 190) adalah sebagai berikut: "analisis laporan keuangan yaitu menguraikan pos-pos laporan keuangan menjadi unit informasi yang lebih kecil dan melihat hubungannya yang bersifat signifikan atau yang mempunyai makna antara satu dengan yang lainnya baik antara data kuantitatif maupun data non-kuantitatif dengan tujuan untuk mengetahui kondisi keuangan lebih dalam yang sangat penting dalam proses menghasilkan keputusan yang sangat tepat”. 


\subsection{Rasio Keuangan}

Menganalisis laporan keuangan berarti mengevaluasi tiga karakteristik dari perusahaan, yaitu likuiditas, aktivitas, solvabilitas, profitabilitas yang menjadi faktor prnting yang harus diperhatikan oleh penganalisa.

1. Likuiditas menunjukan kemampuan suatu perusahaan untuk memenuhi kewajiban keuangannya yang harus segera dipenuhi, atau kemampuan perusahaan untuk memenuhi kewajiban pada saat ditagih.

2. Profitabilitas menunjukan kemampuan perusahaan untuk menghasilkan laba selama periode tertentu.

3. Solvabilitas menunjukan kemampuan perusahaan untuk memenuhi kewajiban keuangan apabila perusahaan tersebut dilikuidasikan baik kewajiban keuangan jangka pendek maupun jangka panjang.

4. Aktivitas menunjukan kemampuan perusahaan untuk mengukur seberapa efektif hasil guna perusahaan menggunakan sumber dayanya.

Secara umum,rasio keuangan dibagi menjadi 4 jenis, antara lain: rasio likuiditas, rasio solvabilitas, rasio aktivitas, dan rasio profitabilitas.

\section{Rasio Likuiditas}

Pengertian rasio likuiditas menurut Darsono, et al. (2004: 51) adalah rasio yang bertujuan untuk mengetahui kemampuan perusahaan dalam membayar kewajiban jangka pendek. Menurut Astuti (2004: 31), posisi likuiditas perusahaan menunjukan kemampuan perusahaan memenuhi kewajiban jangka pendeknya. Likuiditas berhubungan dengan masalah kepercayaan kreditor jangka pendek kepada perusahaan yang ditunjukan oleh besar kecilnya aktiva lancer. Rasio likuiditas, antara lain sebagai berikut:

1. Rasio Lancar / Current Ratio

Rasio lancar adalah pengukuran yang digunakan secara luas untuk mengevaluasi likuiditas perusahaan dan kemampuan membayar utang jangka pendek menurut Weygandt, et al. (2008: 396).

Current Ratio $=\quad \frac{\text { Aktiva Lancar }}{\text { Hutang Lancar }} \times 100 \%$

2. Rasio Cepat / Quick Ratio 
Harahap (2006: 302) mengatakan bahwa rasio ini menunjukan kemampuan aktiva lancar yang paling likuid mampu menutupi utang lancar. Menurut Darsono, et al. (2004: 74), rasio cepat mengukur kemampuan aktiva lancar minus persediaan untuk membayar kewajiban lancar.

\section{Aktiva Lancar - Persediaan}

Quick Ratio

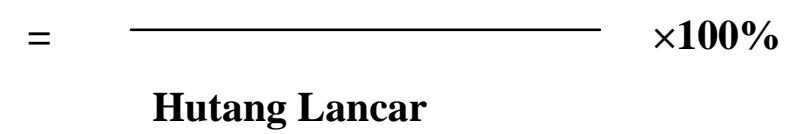

3. Cash Ratio

Rasio ini digunakan untuk mengetahui kemapuan perusahaan untuk membayar kewajiban-kewajiban yang jatuh tempo.Menurut Sutrisno (2009 : 216), menjelaskan bahwa Cash Ratio adalah rasio yang membandingkan antara kas dan aktiva lancar yang bisa segera menjadi uang kas dengan hutang lancar.

Cash Ratio

$$
=\frac{\text { Kas + Efek }}{} \times 100 \%
$$

\section{Hutang Lancar}

\section{Rasio Solvabilitas}

Menurut Raharjaputra (2009: 200), rasio solvabilitas mengukur sejauh mana perusahaan mendanai usahanya dengan membandingkan antara dana sendiri yang telah disetorkan dengan jumlah pinjaman dari para kreditur. Menurut Weygandt, et al. (2008: 406), rasio solvabilitas mengukur kemampuan perusahaan untuk bertahan slama periode waktu yang panjang. Sutrisno (208: 3) membagi rasio solvabilitas menjadi empat macam, yaitu:

1. Debt to Equity Ratio. Rasio hutang dengan modal sendiri merupakan imbangan antara hutang yang dimiliki perusahaan dengan modal sendiri.

\section{Debt to Equity Ratio = $\quad \times 100 \%$ \\ Modal}

2. Debt Ratio. Ratio ini mengukur jumlah aktiva perusahaan yang dibiayai oleh modal yang berasal dari kreditur.

\section{Debt Ratio}

\section{Total Hutang}

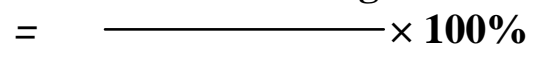

Total Aktiva 


\section{Rasio Profitabilitas}

Astuti (2004: 36) mengemukakan bahwa profitabilitas adalah kemampuan suatu perusahaan untuk menghasilkan laba dan satu-satunya ukuran profitabilitas yang paling penting adalah laba bersih. Menurut Harahap (2006: 304) rasio profitabilitas menggambarkan kemampuan perusahaan mendapatkan laba melalui semua kemampuan dan sumber yang ada seperti kegiatan penjualan, kas, modal, jumlah karyawan, jumlah cabang dan sebagainya.

1. Net Margin Ratio. Ratio ini digunakan untuk menghitung tingkat keuntungan yang diperoleh dari penjualan, dengan membagikan antara laba bersih setelah pajak dengan penjualan.

\section{Net Margin Ratio}

Laba bersih setelah pajak

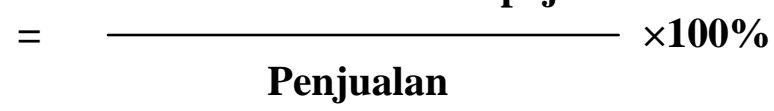

2. Return on Equity. Rasio ini menggambarkan kemampuan perusahaan dalam menghasilkan keuntungan dengan modal sendiri yang dimiliki.

\section{Laba Bersih Setelah Pajak}

Return On Equity

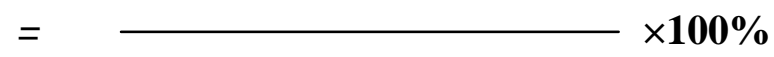

\section{Modal}

3. Return on Investement. Rasio ini menggambarkan kemampuan perusahaan untuk menghasilkan keuntungan yang akan digunakan untuk menutupi investasi yang digunakan.

Return On Investment

\section{Laba Bersih Setelah Pajak}

Total Aktiva

\section{Rasio Aktivitas}

Rasio Aktivitas menurut Raharjaputra (2009: 199) yaitu rasio yang mengukur seberapa efektif (hasil guna) perusahaan menggunakan sumber dayanya.

Menurut Harahap (2006: 308) rasio ini menggambarkan aktivitas yang dilakukan perusahaan dalam menjalankan operasinnya, baik dalam kegiatan penjualan, pembelian, dan kegiatan lainnya.

Current asset Turn Over $=\frac{\text { Penjualan Bersih }}{\text { Aktiva Lancar }} \times 100 \%$




\begin{tabular}{|c|c|c|}
\hline \multirow{2}{*}{ Fixed Asset Turn Over } & \multirow{2}{*}{$=$} & Penjualan Bersih \\
\hline & & $\begin{array}{c}\text { Aktiva Tetap } \\
\text { Penjualan Bersih }\end{array}$ \\
\hline Total Asset Turn Over & $=$ & Total Aktiva \\
\hline
\end{tabular}

\subsection{Hipotesis}

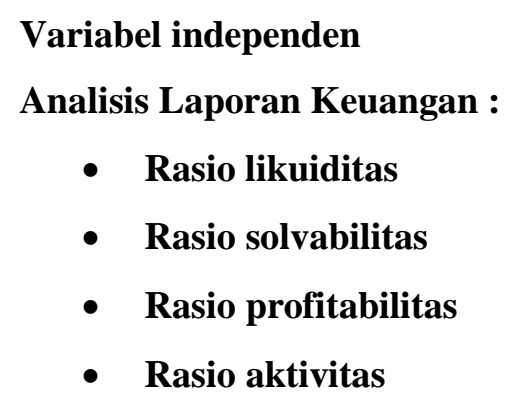

Variabel dependen Kinerja keuangan Perusahaan:

- Current Ratio

- Quick Ratio

- Cash Ratio

- Debt to Equity Ratio

- Debt Ratio

- Net Margin Ratio

- Return on Equity

- Return on Investment

- Current Asset Turn Over

\section{Gambar 1 Paradigma Penelitian}

\section{Metodologi Penelitian}

\subsection{Objek Penelitian}

Objek peneitian ini adalah PT. BUDI SATRIA WAHANA MOTOR yang beralamat di JL. Yos Sudarso No. 85 Bandar Lampung.

\subsection{Sumber Data}

Data yang digunakan dalam penelitian ini adalah data sekunder, data yang diperoleh dari perusahaan sebagai objek penelitian yang sudah diolah dan terdokumentasi di perusahaan, misalnya sejarah perusahaan, struktur organisasi, dan laporan keuangan perusahaan. Serta studi pustaka literature, majalah, dan dokumen yang berkaitan dengan analisis laporan keuangan. Sebagai bahan analisa dalam penelitian ini, maka data yang diperoleh dalam penelitian ini antara lain : 
1. Neraca perusahaan per 31 Desember 2009, 2010, 2011 dan 2012

2. Laporan Laba Rugi Perusahaan untuk tahun yang berakhir 31 Desember 2009, 2010, 2011, dan 2012.

\subsection{Metode Pengumpulan Data}

Penelitian ini dilakukan dengan cara Studi Pustaka ( library research ) yaitu Dilakukan dengan cara mengumpulkan data perpustakaan dengan cara membaca dan menggunakan literature-literatur yang berhubungan dengan pembahasan yang diangkat dalam penulisan laporan ini.

\subsection{Analisis Data}

Dalam menganalisis data penulis menggunakan metode sebagai berikut:

1. Metode Deskriptif, menurut Sugiyono (2001; 204) metode deskriptif, yaitu dengan mengumpulkan, mengelolah, dan menginterpretasikan data yang diperoleh sehingga dapat memberikan gambaran yang jelas mengenai keadaan yang diteliti.

2. Analisis Rasio, dalam melakukan penelitian ini analisis terhadap laporan keuangan perusahaan, penulis menggunakan alat analisis yang dikutip dari Sutrisno (2008:215).

\section{Hasil dan Pembahasan}

\subsection{Analisis Ratio}

Analisis ratio dimaksudkan sebagai gambaran suatu hubungan atau perbandingan dari jumlah pos tertentu dengan jumlah pos lain, sehingga dapat memberikan gambaran kepada pihak lain tentang baik buruknya posisi keuangan yang diperbandingkan dengan ratio standart.

\section{Ratio Likuiditas}

Berikut ini adalah analisa rationya:

- Current ratio

$2009=\frac{\text { Aktiva Lancar }}{\text { Hutang Lancar }} \times 100 \%$

Rp. $\quad 883.828 .975$

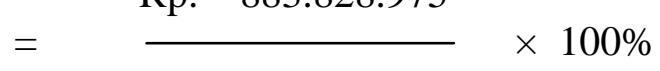




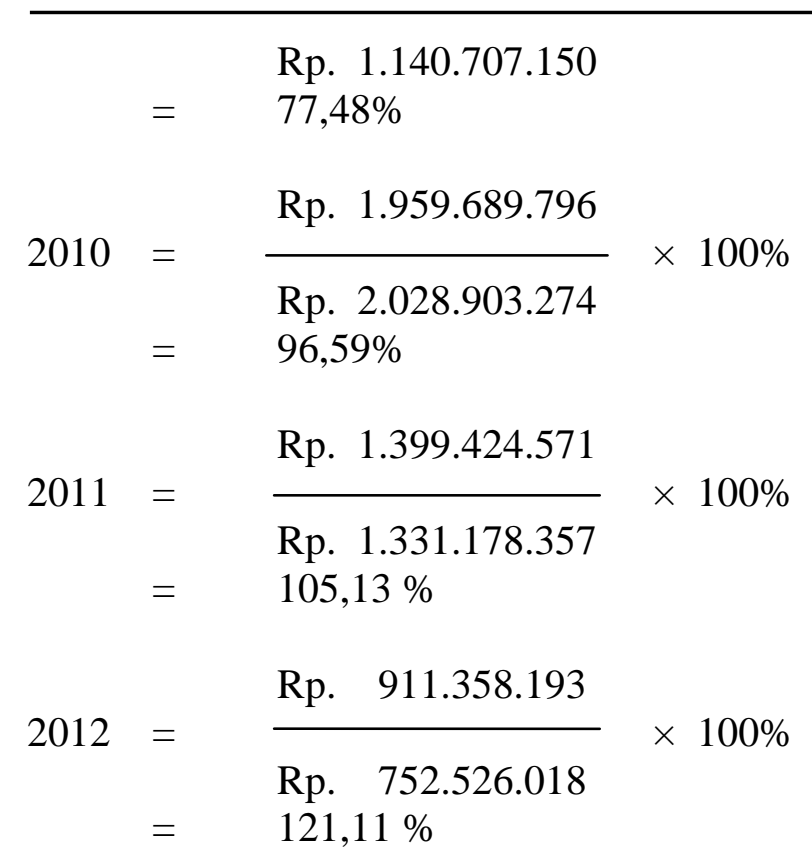

Keadaan current ratio untuk PT.Budi Satria Wahana Motor menunjukan kenaikan dari tahun 2009 ke tahun 2012 sebesar 19,11\% (96,59 - 77,48 \%), hal ini disebabkan karena aktiva lancar naik sebesar Rp. 1.075.860.821 atau sebesar 121,73\% tetapi hutang lancar hanya naik sebesar Rp. 888.196.124 atau naik sebesar 77,86\%. Dari tahun 2010 ke tahun 2011 current ratio naik sebesar 8,54\% (105,13\% - 96,59\%), hal ini disebabkan aktiva lancar turun sebesar Rp. 560.265.225 atau turun sebesar 28,59\% dan hutang lancar turun sebesar Rp. 697.724.899 atau turun sebesar 34,39\% . Tahun 2011 ke tahun 2012 current ratio naik sebesar $15,98 \%(121,11 \%-105,13 \%)$, hal ini disebabkan karena aktiva lancar turun sebesar Rp. 488.066,378 atau sebesar 34,88\% dan hutang lancar sebesar Rp. 578.652.357 atau turun sebesar 43,47\% . Hal ini belum menunjukan kinerja perusahaan karena angka ratio yang dihasilkan oleh perusahaan pada tahun 2009 sampai 2012 belum menunjukan angka ratio standar, dimana menurut Munawir, standar ratio yang umumnya dipakai sekitar $250 \%$ meskipun dari tahun ke tahun ada peningkatan.

- Quick Ratio

$\begin{aligned} 2009 & =\frac{\text { Aktiva Lancar }- \text { Persediaan Barang }}{\text { Hutang Lancar }} \times 100 \% \\ & =\frac{\text { Rp. } 407.399 .915}{\text { Rp. } 1.140 .707 .150} \times 100 \% \\ & =\frac{35,71 \%}{20.979 .533 .098} \times 100 \%\end{aligned}$


Rp. 2.028.903.274

$=48,28 \%$

$\begin{aligned} 2011 & =\frac{\text { Rp. } 844 \cdot 360.446}{\text { Rp. } 1.331 .178 .375} \times 100 \% \\ & =63,43 \%\end{aligned}$

$\begin{aligned} 2012 & =\frac{\text { Rp. } 472.540 .206}{\text { Rp. } 752.526 .018} \times 100 \% \\ & =62,79 \%\end{aligned}$

Dengan melihat keadaan tahun 2009 dan tahun 2010, quick ratio cenderung naik, yaitu sebesar $12,57 \%(48,28 \%$ - 35,71\%), hal ini disebabkan karena aktiva lancar naik sebesar $121,73 \%$, persediaan barang naik $105,73 \%$ dan hutang lancar naik sebesar 77,86\% . Sedangkan dari tahun 2010 ke 2011 naik sebesar 15,15\% (63,43\% - 48,28\%), hal ini disebabkan karena persediaan barang turun sebesar 43,37\% dan aktiva lancar turun sebesar 28,59\% tetapi hutang dagang turun sebesar 34,39\% . Dan dari tahun 2011 ke 2012 menurun sebesar $0,64 \%(62,79 \%-63,43 \%)$, hal ini disebabkan karena persediaan barang turun sebesar 20,94\%, aktiva lancar turun sebesar $34,88 \%$ dan hutang lancar turun sebesar $43,47 \%$. Dengan melihat angka ratio yang dihasilkan perusahaan, maka menunjukan perusahaan belum dapat menjamin membayar hutang-hutang lancarnya dalam waktu singkat tanpa mengandalkan persediaan barang, sebab persediaan barang merupakan aktiva lancar yang memerlukan waktu yang lama untuk menjadi kas. Untuk menjamin hutang lancar tersebut, angka ratio yang dihasilkan perusahaan sebaiknya diatas $200 \%$.

- Cash ratio

$$
\begin{aligned}
2009 & =\frac{\text { Kas }+ \text { Efek }}{\text { Hutang Lancar }} \times 100 \% \\
& =\frac{\text { Rp. } 9.057 .074}{\text { Rp. } 1.140 .707 .150} \times 100 \% \\
& =\frac{0,79 \%}{2010} \\
& =\frac{\text { Rp. } 2.021 .717}{\text { Rp. } 2.028 .903 .274} \times 100 \% \\
& =0,10 \%
\end{aligned}
$$




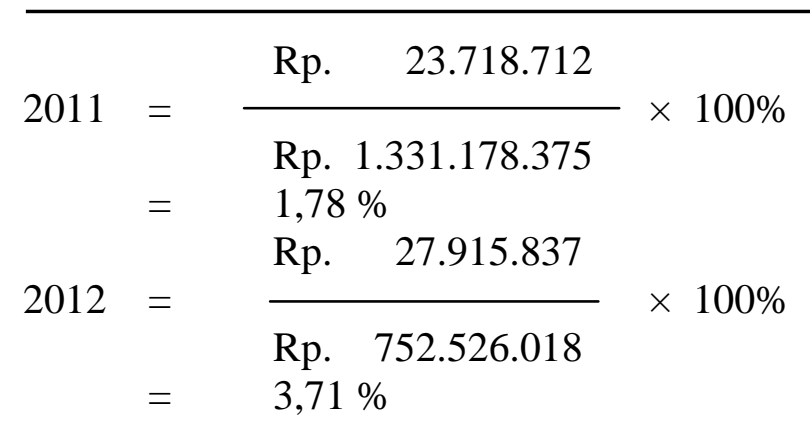

Keadaan cash ratio tidak menunjukan kondisi yang likuid, karena pada tahun 2009 rationya $0,79 \%$ dan pada tahun 2010 turun menjadi $0,10 \%$, hal ini disebabkan karena kas mengalami penurunan sebesar 77,68\% sedangkan hutang lancar mengalami peningkatan sebesar 77,86\% . Pada tahun 2011 naik menjadi 1,78\%, hal ini disebabkan karena kas mengalami peningkatan sebesar 1.073,20\% dan hutang lancar turun sebesar 34,39\% . Tahun 2012 naik menjadi 3,71\%, hal ini disebabkan karena kas naik sebesar 17,70\% dan hutang lancar turun sebesar 43,47\% . Ini jauh dari kemampuan cash untuk menjamin hutang-hutang lancar, hal ini mencerminkan perusahaan tidak mampu menjamin hutang-hutang lancar dengan kas yang tersedia. Untuk menjamin hutang lancar tersebut, angka ratio yang dihasilkan perusahaan sebaiknya sekitar $150 \%$.

\section{Ratio Solvabilitas}

Berikut ini adalah analisa rationya:

- Debt to equity ratio

$$
\begin{aligned}
2009 & =\frac{\text { Total Modal }}{\text { Total Hutang }} \times 100 \% \\
& =\frac{\text { Rp. } 96.890 .435}{\text { Rp. } 1.140 .707 .15} \times 100 \% \\
& =\frac{8,49 \%}{\text { Rp. } 192.453 .815} \\
2010 & =\frac{\text { Rp. } 2.028 .903 .274}{9,49 \%} \\
& =\frac{\text { Rp. } 250.887 .867}{\text { Rp. } 1.331 .178 .375} \times 100 \% \\
& =18,85 \%
\end{aligned}
$$




$\begin{aligned} 2012 & =\frac{\text { Rp. } 291.885 .088}{\text { Rp. } 752.526 .018} \times 100 \% \\ & =38,79 \%\end{aligned}$

Kondisi atau keadaan keuangan perusahaan menurut ratio ini kurang baik, dimana kondisi keuangan dari tahun 2009 sampai 2012 melebihi modal sendiri, yaitu ratio pada tahun 2009 sebesar 8,49\% dan pada tahun 2010 naik menjadi 9,49\%, ini disebabkan total modal mengalami kenaikan sebesar 98,63\%, sedangkan hutang lancar hanya mengalami kenaikan sebesar 77,86\% . Pada tahun 2011 naik menjadi 18,85\%, hal ini disebabkan karena total modal naik sebesar 30,36\% dan hutang lancar turun sebesar 34,39\%. Dan tahun 2012 naik menjadi 38,79\% ini karena total modal naik sebesar 16,34\% dan hutang lancar turun sebesar $43,47 \%$. Dengan melihat ratio yang dihasilkan perusahaan, berarti seluruh aktiva usahanya lebih banyak dibiayai oleh pinjaman dari pihak luar yang mengakibatkan beban usaha lebih besar yaitu kewajiban melunasi hutang-hutang dan kewajiban membayar bunganya. Untuk menjamin hutang tersebut, angka ratio yang dihasilkan perusahaan sebaiknya diatas $150 \%$.

- Debt ratio

$$
\begin{array}{rlr}
2009 & =\frac{\text { Total Aktiva }}{\text { Total Hutang }} & \times 100 \% \\
& =\frac{\text { Rp. } 1.237 .597 .585}{\text { Rp. } 1.140 .707 .150} & \\
& =\frac{100 \%}{108,49 \%} & \\
2010 & =\frac{\text { Rp. } 2.221 .357 .089}{\text { Rp. } 2.028 .903 .274} & \\
& =\frac{109,49 \%}{\text { Rp. } 1.582 .066 .242} & \\
2011 & =\frac{\text { Rp. } 1.331 .178 .375}{\text { Rp. } 1.044 .411 .106} & \times 100 \% \\
2012 & =\frac{\text { Rp. } 752.526 .018}{138,79 \%} & \times 100 \%
\end{array}
$$

Dengan melihat aktiva yang dimiliki oleh perusahaan, menunjukan posisi yang cukup baik, karena hutangnya dapat dijamin dengan aktiva yang tersedia. Hal ini terlihat dari angka 
ratio yang dihasilkan perusahaan dari tahun 2009 sebesar 108,49\% naik menjadi 109,49\% ditahun 2010,hal ini disebabkan oleh karena total aktiva mengalami kenaikan sebesar 79,49\%, sedangkan hutanng lancar mengalami kenaikan hanya sebesar 77,86\%. Tahun 2011 mengalami kenaikan menjadi $118,85 \%$, hal ini disebabkan karena total aktiva mengalami penurunan sebesar $28,78 \%$ sedangkan hutang lancar mengalami penurunan hingga mencapai 34,39\% . Dan pada tahun 2012 naik menjadi 138,79\%. Hal ini disebabkan dari total aktiva turun sebesar 33,98\% dan hutang lancar turun sebesar 43,47\%. Tahun 2011 mengalami kenaikan menjadi $118,85 \%$, hal ini disebabkan karena total aktiva mengalami penurunan sebesar 28,78\% sedangkan hutang lancar mengalami penurunan hingga mencapai 34,39\% . Dan pada tahun 2012 naik menjadi 138,79\%. Hal ini disebabkan dari total aktiva turun sebesar 33,98\% dan hutang lancar turun sebesar 43,47\% . Dari analisis ini, perusahaan telah menunjukan angka ratio yang baik, karena dengan aktiva yang ada mampu membayar hutang yang ada, dimana angka telah mencapai $150 \%$.

\section{Ratio Profitabilitas}

Berikut ini adalah analisa rationya:

- Net margin ratio

$$
\begin{aligned}
& 2009=\frac{\text { Laba Bersih Setelah Pajak }}{\text { Penjualan }} \times 100 \% \\
& =\frac{\text { Rp. } 53.225 .529}{\text { Rp. } 1830.856 .209} \times 100 \% \\
& =\quad 2,91 \%
\end{aligned}
$$

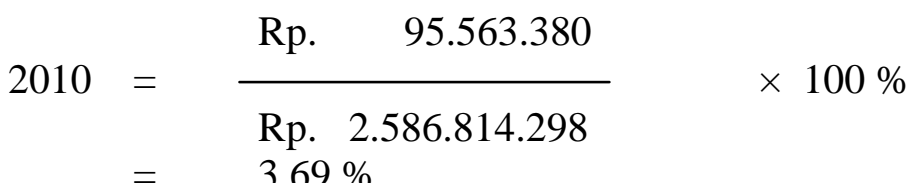

$$
\begin{aligned}
& 2011=\frac{\text { Rp. } 58.434 .052}{\text { Rp. } 2.245 .967 .360} \times 100 \% \\
& 2012=\frac{\text { Rp. } 40.997 .221}{2} \times 100 \% \\
& =\quad 3,16 \%
\end{aligned}
$$


Dilihat dari hasil analisa pada tahun 2009 dan 2010 Net Margin Ratio mengalami peningkatan, pada tahun 2009 mencapai 2,91 \% dan pada tahun 2010 naik menjadi 3,69\%, hal ini disebabkan karena laba bersih mengalami kanaikan sebesar 79,54\% dan juga penjualan mengalami kenaikan sebesar 41,29\%. Hal ini berarti, bahwa setiap rupiah hasil penjualan sebesar $2,91 \%$ rupiah yang dapat direalisasikan menjadi laba dan kemudian pada tahun 2010 realisasi laba tersebut naik 0,78\% menjadi 3,69\%, hal ini disebabkan kenaikan penjualan diikuti dengan naiknya biaya-biaya yang terjadi pada tahun 2010. Pada tahun 2011 net margin ratio mengalami penurunan sebesar $1,09 \%(3,69 \%-2,60 \%)$, hal ini berarti setiap rupiah penjualan sebesar 2,60\% rupiah yang dapat direalisasikan menjadi laba. Kenaikan ini disebabkan karena penurunan penjualan sebesar 13,18\% dan kenaikan biaya yang terjadi pada tahun 2011 yang menyebabkan laba bersih setelah pajak turun sebesar 38,85\% . Sedangkan, pada tahun 2012 ratio ini mengalami kenaikan menjadi sebesar 3,16\%, hal ini disebabkan karena penjualan turun sebesar $42,32 \%$ dan laba turun sebesar $29,84 \%$.

- Return on equity

$$
\begin{aligned}
& \text { Laba Bersih Setelah Pajak }
\end{aligned}
$$

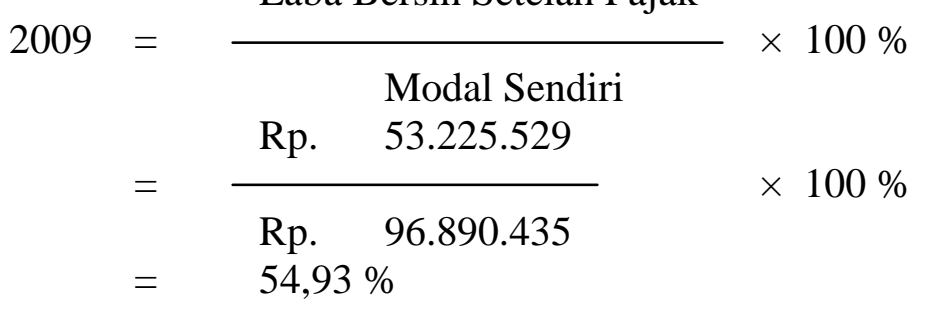

$$
\begin{aligned}
& 2010=\frac{\text { Rp. } 95.563 .380}{\begin{array}{l}
\text { Rp. } 192.453 .815 \\
49,66 \%
\end{array}} \times 100 \% \\
& \begin{aligned}
2011 & =\frac{\text { Rp. } 58.434 .052}{\text { Rp. } 250.887 .867} \times 100 \% \\
& =23,29 \%
\end{aligned} \\
& \begin{aligned}
2012 & =\frac{\text { Rp. } 40.997 .221}{\text { Rp. } 291.885 .088} \times 100 \% \\
& =14,05 \%
\end{aligned}
\end{aligned}
$$

Ratio pengembalian modal sendiri merupakan ratio yang menghubungkan antara laba bersih setelah pajak dengan modal sendiri yang digunakan untuk operasi usaha, untuk menunjukan tingkat keuntungan atau laba yang diperoleh dari laba sendiri. Pada tahun 2009 
ratio pengembalian sendiri yang dicapai sebesar 54,93\% dan tahun 2010 turun sebesar 5,27\% menjadi 49,66\%, hal ini disebabkan oleh laba bersih setelah pajak naik sebesar 98,63\% . Pada tahun 2011 turun menjadi 23,29\%, hal ini disebabkan oleh laba bersih setelah pajak turun sebesar 38,85\% dan modal sendiri mengalami kenaikan sebesar 30,36\% dan pada tahun 2012 turun menjadi 14,05\%, hal ini disebabkan oleh laba bersih setelah pajak turun sebesar 29,84\% dan modal sendiri mengalami kenaikan sebesar 16,34\%. Angka ini menunjukan bahwa setiap rupiah modal sendiri yang dimiliki perusahaan dapat menghasilkan keuntungan yaitu $54,83 \%$ pada tahun $2009,49,66 \%$ pada tahun $201023,29 \%$ pada tahun 2011 dan $14,05 \%$ pada tahun 2012.

- Return on investment

$$
\begin{aligned}
& 2009=\frac{\text { Laba Bersih Setelah Pajak }}{\text { Total Aktiva }} \times 100 \% \\
& \begin{array}{ll}
\text { Rp. } \quad 53.225 .529 & \times 100 \%
\end{array} \\
& \begin{array}{l}
=\frac{\text { Rp. } 1.237 .597 .585}{4,30 \%} \\
=\quad \times 100 \%
\end{array} \\
& \begin{aligned}
2010 & =\frac{\text { Rp. } 95.563 .380}{\text { Rp. } 2.221 .357 .089} \times 100 \% \\
& =4,30 \%
\end{aligned} \\
& \begin{aligned}
2011 & =\frac{\text { Rp. } 58.434 .052}{\text { Rp. } 1.582 .066 .242} \times 100 \% \\
& =3,69 \%
\end{aligned} \\
& \begin{aligned}
2012 & =\frac{\text { Rp. } 40.997 .221}{\text { Rp. } 1.004 .441 .106} \times 100 \% \\
& =3,93 \%
\end{aligned}
\end{aligned}
$$

Ratio ini menunjukan hubungan antara laba bersih setelah pajak dengan total aktiva yang dipergunakan. Pada tahun 2009 ratio yang dicapai sebesar 4,30\%, hal ini dikarenakan laba bersih mengalami kenaikan sebesar $79,54 \%$ dan total aktiva mengalami kenaikan sebesar 79,49\% , pada tahun 2010 ROI tetap yaitu sebesar 4,30\% dan pada tahun 2011 ROI turun menjadi 3,69\%, hal ini dikarenakan laba bersih mengalami penurunan sebesar 38,85\% dan aktiva mengalami penurunan sebesar $28,78 \%$ dan pada tahun 2012, ROI naik menjadi $3,93 \%$ hal ini dikarenakan laba turun sebesar $29,84 \%$ dan aktiva turun 33,98\% . Jadi setiap 
rupiah jumlah investasi atau aktiva yang digunakan dalam rangka mencapai hasil tertentu sebesar 4,30\% yang dapat direalisasikan menjadi laba pada tahun 2009, pada tahun 2010 realisasi labanya tetap yaitu 4,30\% pada tahun 2011 turun menjadi 3,69\% dan pada tahun 2012 naik kembali menjadi 3,93\% dari satu rupiah aktiva yang digunakan. Dengan melihat data ini maka dapat diambil kesimpulan bahwa setiap tahun ROI mengalami kenaikan.

\section{Ratio Aktivitas}

Berikut ini adalah analisa rationya :

- Current asset turn over

$$
\begin{aligned}
& 2009=\frac{\text { Penjualan Bersih }}{\text { Aktiva Lancar }} \\
& \text { Aktiva Lancar } \\
& \text { Rp. } \quad 1.830 .856 .209 \quad \text { Kali } \\
& =\quad \text { Rp. } 883.828 .975 \quad \text { Kali } \\
& =\quad 2,07 \text { Kali } \\
& =\quad 1,32 \text { Kali } \\
& 2011=\frac{\text { Rp. } 2.245 .967 .360}{\text { Kali }} \\
& =\quad \begin{array}{ll}
\text { Rp. } \quad 1.390 \\
1,60 \mathrm{Kali}
\end{array} \\
& 2012=\frac{\text { Rp. }}{1.295 .502 .020} \quad \text { Kali } \\
& =\quad 1,42 \text { Kali }
\end{aligned}
$$

Perputaran aktiva lancar terhadap penjualan yang terjadi pada tahun 2009 sebesar 2,07 kali, mengalami penurunan pada tahun 2010 menjadi sebesar 1,32 kali, hal ini berarti perusahaan belum mencerminkan kinerja keuangannya dalam mengelolah perputaran aktiva lancar. Dimana ratio yang dihasilkan telah mengalami penurunan sebesar 0,75 kali $(2,07-$ 1,32), hal ini dikarenakan penjualan bersih naik sebesar $41,29 \%$ dan aktiva lancar naik sebesar 121,73\%. Tetapi dari tahun 2010 ke 2011 mengalami kenaikan menjadi 1,60 kali, ini dikarenakan penjualan bersih turun sebesar $13,18 \%$ dan aktiva lancar sebesar $28,59 \%$ dan tahun 2012 mengalami penurunan kembali menjadi 1,42 kali, ini disebabkan karena penjualan bersih turun sebesar 43,32\% dan aktiva lancar turun sebesar 34,88\%. Hal ini 
berarti perusahaan mengalami kemunduran dalam kinerja keuangannya didalam mengelola perputaran aktiva lancar.

- Fixed asset turn over

\begin{tabular}{|c|c|c|c|}
\hline \multirow{2}{*}{2009} & \multirow{2}{*}{$=$} & \multicolumn{2}{|r|}{ Penjualan Bersih } \\
\hline & & Rp. & $\begin{array}{l}\text { Aktiva Tetap } \\
1.830 .856 .209\end{array}$ \\
\hline & $=$ & Rp. & 338.768 .610 \\
\hline & $=$ & 5,40 & ali \\
\hline \multirow{3}{*}{2010} & \multirow{2}{*}{$=$} & $\mathrm{Rp}$. & 2.856.814.298 \\
\hline & & $\mathrm{Rp}$. & 246.667 .293 \\
\hline & $=$ & $1 ., 49$ & Cali \\
\hline \multirow{3}{*}{2011} & \multirow{2}{*}{$=$} & Rp. & 2.245.967.360 \\
\hline & & Rp. & 167.641 .671 \\
\hline & $=$ & 13,4 & Kali \\
\hline \multirow{3}{*}{2012} & \multirow{2}{*}{$=$} & Rp. & 1.295 .502 .020 \\
\hline & & $\mathrm{RP}$. & 118.052 .913 \\
\hline & $=$ & $10,9^{\prime}$ & Kali \\
\hline
\end{tabular}

Perputaran aktiva tetap terhadap penjualan pada tahun 2009 amgka perputarannya mencapai 5,40 kali dan mengalami peningkatan pada tahun 2010 menjadi sebesar 10,49 kali, hal ini dikarenakan penjualan bersih meningkat sebesar $41,29 \%$ dan aktiva tetap menurun sebesar $27,19 \%$, sehingga mencerminkan peningkatan perputaran aktiva tetap dan hal ini menunjukan kemampuan perusahaan didalam mengelola aktiva tetap dan hal ini menunjukan kemampuan perusahaan didalam mengelola aktiva tetapnya terhadap pencapaian penjualan. Tetapi pada tahun 2011 mengalami peningkatan menjadi 13,40 kali, ini disebabkan karena penjualan bersih menurun sebesar $13,18 \%$ dan aktiva tetap menurun sebesar $32,04 \%$. Dan pada tahun 2012 turun menjadi 10,97 kali, hal ini dikarenakan penjualan bersih menurun sebesar $42,32 \%$ dan aktiva tetap turun sebesar $29,58 \%$. Dengan melihat data tersebut dapat disimpulkan bahwa pada tahun 2011 kemampuan perusahaan didalam mengelola aktiva tetapnya terhadap pencapaian penjualan menurun. 
- Total asset turn over

$$
\begin{aligned}
& \text { Penjualan Bersih } \\
& 2009=- \text { Kali } \\
& \text { Total Aktiva } \\
& \text { Rp. } \quad 1.830 .856 .209 \\
& =\frac{}{\text { Rp. } \quad 1.237 .597 .585} \text { Kali } \\
& =\quad 1,48 \text { Kali } \\
& 2010=\frac{\text { Rp. } 2.586 .814 .298}{\text { Rp. } 2.221 .357 .089} \text { Kali } \\
& =\quad 1,16 \mathrm{Kali} \\
& 2011=\frac{\text { Rp. } 2.245 .967 .360}{\text { Rp. } 1.582 .066 .242} \text { Kali } \\
& =\quad 1,42 \mathrm{Kali} \\
& 2012=\frac{\text { Rp. } 1.295 .502 .020}{\text { Rp. } 1.044 .411 .106} \text { Kali } \\
& =\quad 1,24 \mathrm{Kali}
\end{aligned}
$$

Keadaan perputaran harta keseluruhan pada PT.Budi Satria Wahana Motor terjadi kenaikan. Pada tahun 2009 perputarannya mencapai 1,48 kali dan tahun 2010 naik menjadi 1,16 kali, hal ini dikarenakan penjualan bersih mengalami kenaikan sebesar 41,29\% dan total aktiva naik sebesar 79,49\% . Dan pada tahun 2010 dan 2011 perputaran hartanya mengalami peningkatan sebesar 0,26 kali $(1,42-1,16)$, ini dikarenakan penjualan maupun total aktiva mengalami penurunan masing-masing sebesar 13,18\% dan 28,78\% . Tetapi pada tahun 2011 ke 2012 terjadi penurunan dari 0,18 kali menjadi 1,24 kali. Hal ini berarti perusahaan mengalami kemunduran dalam kinerjanya dikarenakan penurunan penjualan bersih sebesar $42,32 \%$ dan total aktiva menurun sebesar $33,98 \%$.

\section{Analisa Laporan Laba Rugi yang diperbandingkan}

- Berikut ini adalah tabel perbandingannya : 
Tabel 1

Laporan Rugi Laba yang diperbandingkan

Tahun 2009 dan 2010 dalam Rupiah (Rp)

\begin{tabular}{|c|c|c|c|c|}
\hline PERKIRAAN & 2009 & 2010 & NAIK/TURUN & $\%$ \\
\hline \multicolumn{5}{|l|}{ PENDAPATAN } \\
\hline Penjualan & 1.830.856.209 & 2.586.814.298 & 755.958 .089 & $41,29 \%$ \\
\hline \multicolumn{5}{|l|}{ HARGA POKOK PENJUALAN } \\
\hline Persediaan Awal & 364.933 .362 & 476.429 .060 & 111.495 .698 & $30,55 \%$ \\
\hline Pembelian & 1.533 .935 .828 & 2.636 .726 .028 & 1.102 .790 .200 & $71,89 \%$ \\
\hline Barang Tersedia & 1.898 .869 .190 & 3.113 .155 .088 & 1.214 .285 .898 & $63,95 \%$ \\
\hline Persediaan Akhir & 476.429 .060 & 980.156 .698 & 503.727 .638 & $105,73 \%$ \\
\hline Total & 1.422 .440 .130 & 2.132 .998 .390 & 710.558 .260 & $49,95 \%$ \\
\hline LABA BRUTO & 408.416 .079 & 453.815 .908 & 45.399 .829 & $11,12 \%$ \\
\hline \multicolumn{5}{|l|}{ BIAYA OPERASI } \\
\hline Biaya Penjualan & 153.555 .930 & 149.415 .722 & $(4.140 .208)$ & $-2,70 \%$ \\
\hline Biaya Adm \& Umum & 76.169 .515 & 105.477 .546 & 29.308 .031 & $38,48 \%$ \\
\hline Total Biaya operasi & 229.725 .445 & 254.893 .268 & 25.167 .823 & $10,96 \%$ \\
\hline LABA SETELAH BIAYA OPERASI & 178.690 .634 & 198.922 .640 & 20.232.006 & $11,32 \%$ \\
\hline PENDAPATAN NON OPERASI & - & - & - & - \\
\hline LABA NON OPERASI & 119.340 .105 & 81.766 .260 & $(37.573 .845)$ & $-31,48 \%$ \\
\hline LABA SEBELUM PAJAK & 59.350 .529 & 117.156 .389 & 57.805 .851 & $97,40 \%$ \\
\hline PAJAK PPh 25 & 6.125 .000 & 21.593 .000 & 15.468 .000 & $252,54 \%$ \\
\hline LABA BERSIH & 53.225 .529 & 95.563 .380 & 42.337 .851 & $79,54 \%$ \\
\hline
\end{tabular}

Sumber : data diolah 
Tabel 2

Laporan laba rugi yang diperbandingkan

Tahun 2010 dan 2011 dalam rupiah $(\mathbf{R p})$

\begin{tabular}{|c|c|c|c|c|}
\hline PERKIRAAN & 2010 & 2011 & NAIK/TURUN & $\%$ \\
\hline \multicolumn{5}{|l|}{ PENDAPATAN } \\
\hline Penjualan & 2.586.814.298 & 2.245 .967 .360 & $(340.846 .938)$ & $-13,18 \%$ \\
\hline \multicolumn{5}{|l|}{ HARGA POKOK PENJUALAN } \\
\hline Persediaan Awal & 476.429 .060 & 980.156 .698 & 503.727 .638 & $105,73 \%$ \\
\hline Pembelian & 2.636 .726 .028 & 1.396 .079 .829 & $(1.240 .646 .199)$ & $-47,05 \%$ \\
\hline Barang Tersedia & 3.113.155.088 & 2.376.236.527 & $(736.918 .561)$ & $-23,67 \%$ \\
\hline Persediaan Akhir & 980.156 .698 & 555.064 .125 & $(425.092 .573)$ & $-43,37 \%$ \\
\hline Total & 2.132 .998 .390 & 1.821 .172 .402 & $(311.825 .988)$ & $-14,62 \%$ \\
\hline LABA BRUTO & 453.815 .908 & 424.794 .958 & $(29.020 .950)$ & $-6,39 \%$ \\
\hline \multicolumn{5}{|l|}{ BIAYA OPERASI } \\
\hline Biaya Penjualan & 149.415 .722 & 145.598 .895 & $(3.816 .827)$ & $-2,55 \%$ \\
\hline \multirow{2}{*}{$\begin{array}{l}\text { Biaya Adm \& Umum } \\
\text { Total Biaya Operasi }\end{array}$} & 105.477 .546 & 139.835 .282 & 34.357 .736 & $32.57 \%$ \\
\hline & 254.893 .268 & 285.434 .177 & 30.540 .909 & $11,98 \%$ \\
\hline LABA SETELAH BIAYA OPERASI & 198.922 .640 & 139.360 .781 & $(59.561 .859)$ & $-29,94 \%$ \\
\hline PENDAPATAN NON OPERASI & - & - & - & \\
\hline LABA NON OPERASI & 81.766 .260 & 75.170729 & $(6.595 .531)$ & $-8,07 \%$ \\
\hline \multirow{2}{*}{$\begin{array}{l}\text { LABA SEBELUM PAJAK } \\
\text { PAJAK PPh } 25\end{array}$} & 117.156 .380 & 64.190 .052 & $(52.966 .328)$ & $-45,21 \%$ \\
\hline & 21.593 .000 & 5.756 .000 & $(15.837 .000)$ & $-73,34 \%$ \\
\hline LABA BERSIH & 95.563 .380 & 58.434 .052 & $(37.129 .328)$ & $-38,85 \%$ \\
\hline
\end{tabular}

Sumber : data diolah 


\section{Tabel 3}

Laporan Laba Rugi yang diperbandingkan

Tahun 2011 dan 2012 dalam Rupiah (Rp)

\begin{tabular}{|c|c|c|c|c|}
\hline PERKIRAAN & 2011 & 2012 & NAIK/TURUN & $\%$ \\
\hline \multicolumn{5}{|l|}{ PEDAPATAN } \\
\hline Penjualan & 2.245 .967 .360 & 1.295 .502 .020 & $(950.465 .340)$ & $-42,32 \%$ \\
\hline \multicolumn{5}{|l|}{ HARGA POKOK PENJUALAN } \\
\hline Persediaan Awal & 980.156 .698 & 555.064 .125 & $(425.092 .573)$ & $-43,37 \%$ \\
\hline Pembelian & 1.396.079.829 & 942.268 .146 & $(453.811 .683)$ & $-32,51 \%$ \\
\hline Barang Tersedia & 2.376.236.527 & 1.497.332.271 & $(878.904 .256)$ & $-36,99 \%$ \\
\hline Persediaan Akhir & 555.064 .125 & 438.817 .987 & $(116.246 .138)$ & $-20,94 \%$ \\
\hline Total & 1.821 .172 .402 & 1.058.514.284 & $(762.658 .118)$ & $-41,88 \%$ \\
\hline LABA BRUTO & 424.794 .958 & 236.987 .736 & $(187.807 .222)$ & $-44,21 \%$ \\
\hline \multicolumn{5}{|l|}{ BIAYA OPERASI } \\
\hline Biaya Penjualan & 145.598 .895 & 128.521 .380 & $(17.077 .515)$ & $-11.73 \%$ \\
\hline Biaya Adm \& Umum & 139.835 .282 & 63.372 .970 & $(76.462 .312)$ & $-54,68 \%$ \\
\hline Total Biaya operasi & 285.434 .177 & 191.894 .350 & $(93.539 .827)$ & $-32,77 \%$ \\
\hline LABA SETELAH BIAYA OPERASI & 139.360 .781 & 45.093 .386 & $(94.267 .395)$ & $-67,64 \%$ \\
\hline PENDAPATAN NON OPERASI & - & - & - & \\
\hline LABA NON OPERASI & 75.170 .729 & 939.165 & $(74.231 .564)$ & $-98,75 \%$ \\
\hline LABA SEBELUM PAJAK & 64.190 .052 & 44.154 .221 & $(20.035 .831)$ & $-31,21 \%$ \\
\hline PAJAK PPh 25 & 5.756 .000 & 3.157 .000 & $(2.599 .000)$ & $-45,15 \%$ \\
\hline LABA BERSIH & 58.434 .052 & 40.997 .221 & $(17.436 .831)$ & $-29,84 \%$ \\
\hline
\end{tabular}

Sumber : data diolah

\section{Analisa Ratio}

Berdasarkan hasil perhitungan ratio, yaitu ratio likuiditas, solvabilitas, profitabilitas dan aktivitas, maka keadaan atau posisi keuangan dan kemampuan manajemen menjalankan usaha selama beberapa tahun yakni dari tahun 2009 sampai tahun 2012 dapat dirangkum sebagai berikut : 
Tabel 4

Prosentase Ratio Dari tahun 2009 s/d 2012

\begin{tabular}{|c|c|c|c|c|}
\hline KETERANGAN & 2009 & 2010 & 2011 & 2012 \\
\hline \multicolumn{5}{|l|}{ Ratio Likuiditas } \\
\hline - Current Ratio & $77,48 \%$ & $96,59 \%$ & $105,13 \%$ & $121,11 \%$ \\
\hline - Quick Ratio & $35,71 \%$ & $48,28 \%$ & $63,43 \%$ & $62,79 \%$ \\
\hline - Cash Ratio & $0,79 \%$ & $0,10 \%$ & $1,78 \%$ & $3,71 \%$ \\
\hline \multicolumn{5}{|l|}{ Ratio Solvabilitas } \\
\hline - Debt to equity ratio & $8,49 \%$ & $9,49 \%$ & $18,85 \%$ & $38,79 \%$ \\
\hline - Debt ratio & $108,49 \%$ & $109,49 \%$ & $118,85 \%$ & $138,79 \%$ \\
\hline \multicolumn{5}{|l|}{ Ratio Profitabilitas } \\
\hline - Net Margin Ratio & $2,91 \%$ & $3,69 \%$ & $2,60 \%$ & $3,16 \%$ \\
\hline - Return On Equity & $54,93 \%$ & $49,66 \%$ & $23,29 \%$ & $14,05 \%$ \\
\hline - Return On Investment & $4,30 \%$ & $4,30 \%$ & $3,69 \%$ & $3,93 \%$ \\
\hline \multicolumn{5}{|l|}{ Ratio Aktivitas } \\
\hline - Current Asset Turn & $207,15 \%$ & $132,00 \%$ & $160,49 \%$ & $142,15 \%$ \\
\hline Asset & $540,44 \%$ & $1.048,71$ & $1.339,74$ & $1.097,39$ \\
\hline - Fixed Asset Turn Over & $147,94 \%$ & $\%$ & $\%$ & $\%$ \\
\hline - Total Asset Turn Over & & $116,45 \%$ & $141,96 \%$ & $124,04 \%$ \\
\hline
\end{tabular}

Sumber : data diolah

Berdasarkan tabel diatas, maka secara garis besar dapat disimpulkan sebagai berikut :

\section{Berdasarkan Ratio Likuiditas}

Kondisi current ratio tidak baik untuk menjamin atau memenuhi kewajiban atau hutang lancar, sebab angka rationya belum mencapai standart yaitu $250 \%$, sehingga jaminan hutang lancar hanya mampu dijamin oleh piutang dan persediaan barang dagang yang belum pasti. Sedangkan cash (aktiva yang paling likuid) belum mampu menjamin hutang lancar pada saat jatuh tempo, sehingga secara keseluruhan ratio likuiditas sedikit meragukan atau belum ada kepastian terhadap jaminan hutang lancar pada saat jatuh tempo.

\section{Berdasarkan Ratio Solvabilitas}

Ratio solvabilitas yaitu debt ratio dari komposisi hutang yang ada, cukup baik, karena aktiva yang menjamin seluruh hutang perusahaan mengalami kenaikan yaitu pada tahun 2009 sebesar 108,49\% dan tahun 2010 sebesar 109,49 \%, tahun 2011 sebesar 118,85\% dan tahun 
2012 sebesar 138,79\%, hal ini telah mencerminkan sikap kehati-hatian manajemen dalam mengelolah hutang-hutangnya. Namun, pada debt to equity ratio angkanya belum mencapai $150 \%$, ini berarti jumlah hutang yang ada melebihi modal yang tersedia yang cenderung mengakibatkan pendapatan terkuras untuk membayar bunga pinjaman pihak luar dari pada untuk kepentingan pihak intern. Sehingga mengakibatkan pengurus lebih terkonsentrasi untuk memenuhi pengembalian pinjaman dan biaya daripada memenuhi kepentingan pihak intern.

\section{Berdasarkan Ratio Profitabilitas}

Bila dilihat dari net margin ratio pada tahun 2010 mengalami kenaikan sebesar 2,91\% menjadi 3,69\% dan mengalami penurunan pada tahun berikutnya yaitu pada tahun 2011 menjadi 2,60\% dan pada tahun 2012 menjadi sebesar 3,16\%. Sedangkan return on equity, mengalami penurunan walaupun pada return on investment tidak mengalami perubahan dari tahun 2009 sebesar 4,30\% begitu pula pada tahun 2010, tetapi mengalami penurunan lagi pada tahun berikutnya. Namun bila dilihat secara keseluruhan ratio profitabilitas ini mengalami penurunan, dimana penurunannya disebabkan oleh besarnya jumlah biaya yang terjadi pada tahun 2011 dan besarnya hutang yang ada, sehingga pembiayaannya lebih banyak dijamin oleh pihak luar. Hal ini mengakibatkan biaya yang dikeluarkan hanya untuk biaya-biaya pinjaman saja, sehingga perusahaan kurang dalam mengelola usahanya.

\section{Ratio Aktivitas}

Melalui analisa ratio perputaran harta, hasilnya telah mencerminkan kinerja keuangan didalam mengelola harta yang ada, karena dari tahun 2009 dan tahun 2010 perputarannya telah menunjukan angka ratio yang meningkat. Tetapi pada tahun berikutnya mengalami penurunan, namun secara keseluruhan sudah cukup baik.

\section{Analisa Perbandingan Laporan Keuangan}

Berdasarkan hasil perhitungan analisa perbandingan, maka keadaan atau posisi keuangan dan kemampuan manajemen menjalankan usaha selama beberapa tahun yakni dari tahun 2009 sampai dengan tahun 2012 dapat dirangkum sebagai berikut: 


\section{Tabel 5}

Rangkuman Kenaikan Atau Penurunan Kondisi Keuangan tahun 2009 s/d 2012 dalam Rupiah (Rp)

\begin{tabular}{|l|l|l|l|l|l|l|}
\hline Keterangan & $\mathbf{2 0 0 9 - 2 0 1 0}$ & $\mathbf{\%}$ & $\mathbf{2 0 1 0 - 2 0 1 1}$ & $\mathbf{\%}$ & $\mathbf{2 0 1 1 - 2 0 1 2}$ & $\mathbf{\%}$ \\
\hline Penjualan bersih & 755.958 .089 & $41,29 \%$ & $(340.846 .938)$ & $-13,18 \%$ & $(950.465 .340)$ & $-42,32 \%$ \\
Tot. Biaya oprasional & 25.167 .823 & $10,96 \%$ & 30.540 .909 & $11,98 \%$ & $(93.539 .827)$ & $-32,77 \%$ \\
Laba bersih setelah pajak & 42.337 .851 & $79,54 \%$ & $(37.129 .328)$ & $-38,85 \%$ & $(17.436 .831)$ & $-29,84 \%$ \\
Total aktiva & 983.759 .504 & $79,49 \%$ & $(639.290 .847)$ & $-28,78 \%$ & $(537.655 .136)$ & $-33,98 \%$ \\
Aktiva tetap & $(92.101 .317)$ & $-27,19 \%$ & $(79.025 .622)$ & $-32,04 \%$ & $(49.588 .758)$ & $-29,58 \%$ \\
Aktiva lancar & 1.075 .860 .821 & $121,73 \%$ & $(560.265 .226)$ & $-28,59 \%$ & $(488.066 .377)$ & $-34,88 \%$ \\
Hutang lancar & 888.196 .124 & $77,86 \%$ & $(697.724 .899)$ & $-34,39 \%$ & $(578.652 .357)$ & $-43,47 \%$ \\
Total modal & 95.563 .380 & $98,63 \%$ & 58.434 .052 & $30,36 \%$ & 40.997 .221 & $16,34 \%$ \\
Total passiva & 983.759 .504 & $79,49 \%$ & $(639.290 .847)$ & $-28,78 \%$ & $(537.655 .136)$ & $-33,98 \%$ \\
& & & & & & \\
\hline
\end{tabular}

Sumber : data diolah

Berdasarkan tabel diatas, maka secara garis besar dapat dievaluasi bahwa penjualan yang dihasilkan PT.BUDI SATRIA WAHANA MOTOR dari tahun 2009 sampai dengan tahun 2010 meningkat sebesar Rp. 755.958.089,- sebesar 41,29 \%. Tetapi mengalami penurunan dari tahun 2010 ke tahun 2011 dan dari tahun 2011 ke tahun 2012 masing-masing sebesar Rp. 340.846.938,- dan Rp. 950.465.340,- atau seebsar 13,18 \% dan 42,32\%. Demikian pula dengan neraca, dimana total aktiva maupun total passiva naik dari tahun 2009 ke tahun 2010 sebesar Rp. 983.759.504,- atau sebesar 79,49 \%. Keadaan ini sudah mencerminkan bahwa perusahaan sudah cukup baik. Tapi pada tahun selajutnya mengalami penurunan yang cukup berarti bagi perusahaan yaitu pada tahun 2010 ke tahun 2011 dan tahun 2011 ke tahun 2012 turun masing-masing Rp. 639.290.847,- dan Rp. 537.655.136,atau sebesar 28,78 \% dan 33,98 \%. Hal ini mencerminkan keadaan perusahaan makin menurun dan kurang baik.

\section{Kesimpulan dan Saran}

Berdasarkan perhitungan dan analisa yang telah dilakukan terhadap laporan keuangan, maka penulis dapat menyimpulkan bahwa: 
1. Ratio likuiditas, dimana kas dan bank belum mampu menjamin hutang lancar pada saat jatuh tempo, karena asset lancar lebih terkonsentrasi pada piutang dan persediaan barang.

2. Ratio solvabilitas, walaupun hutang-hutangnya dijamin dengan total aktiva yang tersedia, namun besarnya jumlah hutang tidak sebanding dengan besarnya modal sendiri sehingga pendapatan yang dihasilkan lebih banyak untuk mengembalikan biaya pinjaman dari pada untuk intern.

3. Ratio profitabilitas, dimana ratio ini cenderung menurun. Hal ini berarti pihak perusahaan kurang baik dalam menekan biaya yang terjadi di tahun 2011, sehingga walaupun laba mengalami kenaikan namun hal ini diikuti pula kenaikan biaya-biaya operasionalnya.

4. Ratio aktivitas, perusahaan telah menunjukan ratio yang meningkat.

Dengan demikian dapat disimpulkan bahwa, PT. BUDI SATRIA WAHANA MOTOR disatu sisi telah menghasilkan laba yang meningkat, namun peningkatannya tidak diimbangi dengan kinerja keuangannya didalam mengelola dan menjalankan usaha, serta tidak adanya selektifitas didalam mengoprasionalkan harta yang yersedia, karena meningkatnya laba belum berarti bahwa suatu perusahaan telah berhasil dalam mengelola usahanya. Untuk itu perlu adanya seorang pengelola yang mampu dan berkualitas secara spesifik didalam menjalankan wewenang dan tanggung jawab yang diberikan.

Dari analisis tersebut dapat disimpulkan, bahwa perusahaan telah menunjukan kondisi keuangan yang belum baik, hal ini dilihat dari tahun 2009 dimana neraca meningkat pada tahun 2010. Begitu pula dengan laba bersih yang diperoleh perusahaan, meningkat pada tahun 2011. Walaupun kenaikan laba tersebut diikuti pula oleh biaya operasionalnya, namun peningkatan biaya operasionalnya itu tidak mempengaruhi tingkat laba yang dihasilkan, sebab kenaikan biaya dapat ditutupi dengan peningkatan penjualan bersih perusahaan.

\subsection{Saran}

Dari kesimpulan diatas, maka saran yang dapat saya berikan adalah sebagai berikut :

1. Pada ratio likuiditas, sebaiknya perusahaan melakukan pengendalian terhadap persediaan barang dagangnya, yaitu dengan cara meningkatkan penjualan dan mengurangi biayanya . 
2. Pada ratio solvabilitas, sebaiknya perusahaan melakukan penjualan terhadap aktiva yang kurang berguna bagi kegiatan usaha, untuk menambah modal perusahaan.

3. Pada ratio profitabilitas, sebaiknya perusahaan melakukan pengendalian terhadap biaya yang dikeluarkan oleh perusahaan, dimana sebaiknya perusahaan menekan biaya, sebab kenaikan laba haruslah diimbangi pula dengan pengeluaran biaya operasionalnya.

4. Pada ratio aktiva, sebaiknya perusahaan harus meningkatkan lagi kinerja keuangan perusahaan agar memperoleh keadaan yang lebih baik.

5. Pengurus hendaknya melakukan analisa ratio untuk mengetahui lebih dalam lagi tentang kondisi atau keadaan keuangan perusahaan.

\section{Daftar Pustaka}

Astuti, Dewi. 2004. Manajemen Keuangan Perusahaan, Edisi Pertama.

Penerbit.Ghalia Indonesia.

Baridwan, Zaki .2008. Intermediate Accounting. Edisi delapan. Cetakan kedua. BPFE-Yogyakarta.

Erick A Helfert, 1993, Teknik Analisa Keuangan, diterjemahkan oleh Wisnu Widjaya dan Moh. Badjuri, Erlangga, Jakarta.

Harahap, Sofyan Syafri. 2006. Analisis Kritis atas Laporan Keuangan. Edisi Pertama. Penerbit PT Raja Grafindo Persada.

Ikatan Akuntansi Indonesia, 2002, Standar Akuntansi Keuangan, Salemba Empat, Jakarta.

Kasmir, 2003. Pengantar Manajemen keuangan, Edisi Pertama. Kencana Prenada Media Grup. Jakarta.

Munawir, 2010, Analisis Laporan Keuangan. Edisi keempat. Penerbit. Liberty, Yogyakarta.

Sugiarso, G dan Winarwi. 2006. Manajemen Keuangan. Cetakan kedua. MediaPersindo, Yokyakarta.

Weygandt, Jerry dan kieso, Donald dan Kimmel, Paul D. 2007. Accounting

Principles, Edisi 7. Penerbit. Salemba Empat. 